\title{
The study of traditional food HACCP through project- based learning in food chemistry course
}

\author{
Nova Kurnia ${ }^{1}$ Liliasari $^{2}$, Dede Robiatul Adawiyah ${ }^{3}$, Florentina Maria Titin Supriyanti ${ }^{2}$ \\ \{novakimia88@yahoo.com¹, liliasari@upi.edu ${ }^{2}$, dede_adawiyah@apps.ipb.ac.id ${ }^{3}$ \}
}

\begin{abstract}
Department of Chemistry Education of IKIP Mataram, Jalan Pemuda No 59A Mataram ${ }^{1}$, Student of Science Education Program on School of Postgraduate Studies, Indonesia University of Education, Bandung, Indonesia, Jalan Dr.Setiabudhi No 229 Bandung $^{1}$, Science Education Program, School of Postgraduate Studies, Indonesia University of Education, Bandung, Indonesia, Jalan Dr.Setiabudhi No 229 Bandung $^{2}$, Department of Food Science and Technology of IPB University, Jalan Raya Dramaga Bogor ${ }^{3}$.
\end{abstract}

\begin{abstract}
Food was likely to be contaminated by hazards during processing steps. On the other side, food safety was the main prerequisite for consumption. Nowadays, the hazard analysis critical control point (HACCP) has been implemented as a food safety assurance system. This research aimed to know the student's ability to reviewing traditional food HACCP through project-based learning in a food chemistry course. This research employed a descriptive method as a research design. The subjects of the research were 16 students eight semesters of a chemistry education program at one of the colleges in Mataram City. To collect data, the instrument of performance assessment rubrics and questionnaires were used. To conclude, the data indicated that students were able to review traditional food HACCP in terms of raw material and processing step through projectbased learning. They were very enthusiastic about the project activities due to it was related to their daily culture.
\end{abstract}

Keywords: traditional food, HACCP, project-based learning, food chemistry.

\section{Introduction}

The challenges of food safety in the 21 st century are complex. One of the challenges is food poisoning in many developing countries, causing losses to the economic and health sectors [1]. Data from The National Agency of Drug and Food Control (NADFC) in 2017 reported 53 cases of food poisoning that caused as many as 5,293 people were exposed, 2,041 people were sick and 3 people died. The cause of food poisoning generally comes from household cooking, snacks, processed foods and ready to eat foods that are contaminated by microbiological and chemical contaminants [2]. The contamination arises due to the weak handling of food safety at multiple steps of processing raw materials that are not optimal. So we need knowledge and good safety practices to close the chance of contamination by hazards.

The role of food safety management systems in safe food production is crucial. Although food contains high nutrition and tastes good, if it is not safe it is not classified as food. Currently, hazard analysis critical control points (HACCP) are known as food safety assurance systems. HACCP is a preventive system of food safety management based on product design, hazard analysis, and process control [3]. HACCP's main key is to anticipate hazards and identify control 
points that prioritize preventive action rather than rely on final food product testing. By implementing HACCP, all steps involved in food production and preparation are systematically evaluated. HACCP was implemented by many food industries ranging from dairy products, seafood processing, and many more [4, 5]. Even HACCP can also be used in traditional food processing [6].

Previous studies report that traditional food can be used as a source of learning about food safety through the course of food chemistry [7]. Traditional food is generally produced by peoples with indigenous knowledge and simple equipment that is also likely to be contaminated with hazard [8]. Food chemistry course gives space for food safety topics especially HACCP because it also studies changes in food that can produce compounds detrimental to health. For example, the formation of histamine in fish storage, polyaromatic hydrocarbons (PAHs) during the frying process and the hydrogen cyanide content is naturally present in cassava leaves [911]. On the other hand, the level of knowledge and practice of students about food safety is still relatively low $[12,13]$. Students have busy activities so they tend to pay less attention to food safety. Therefore, educational programs are needed that aim not only to provide knowledge but also encourage students to practice food safety in the form of HACCP studies.

To study the HACCP topic, we need an effective learning model that trains knowledge and skills at the same time. One effective learning model trains knowledge and skills in real-world learning is project-based learning (PjBL) [14]. PjBL has roots in constructivist learning and discovery-based methods, both of which rely on the inquiry process and students' ability to devise solutions based on their individual perspective and thinking. PjBL involves students in authentic learning through the project which must be challenging, confronting issues, attacking problems, seeking a solution, and impacting the community [15]. Students work in small groups and have the autonomy to develop their projects to make learning become interesting and meaningful [16]. Therefore, PjBL is expected to help students study HACCP traditional food effectively and more interestingly.

\section{Methods}

This study used a descriptive study. In educational research, the most common descriptive methodology is when researchers summarize the characteristics of individuals or groups. It also includes identifying the achievement of various groups of students or their attitudes [17]. Participants in this study consisted of 16 fourth-year from the chemistry education department at one of the tertiary institutions in West Nusa Tenggara province. Participants were divided into four small groups. Each group worked on one traditional food of Lombok island. Traditional foods of Lombok which are being the project material are sate pusut, poteng reket, sate bulayak and pelecing kangkung (figure 1). Then each group works on the project according to the syntax of PjBL (figure 2) for 2 weeks.

The final product of the PjBL is the Lombok traditional food HACCP document. Final product evaluation uses HACCP performance assessment rubric which includes several components including product description, processing flow diagram, hazard analysis, determination of critical control points and preventive measures. In addition, the response of students to the PjBL activity was also evaluated using a questionnaire.
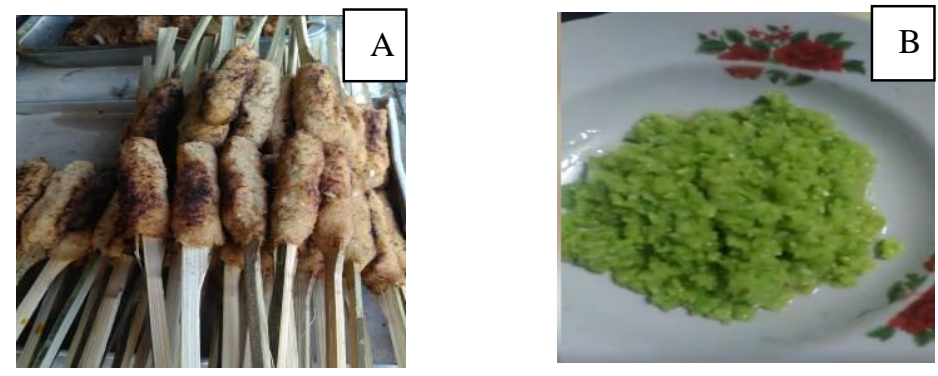

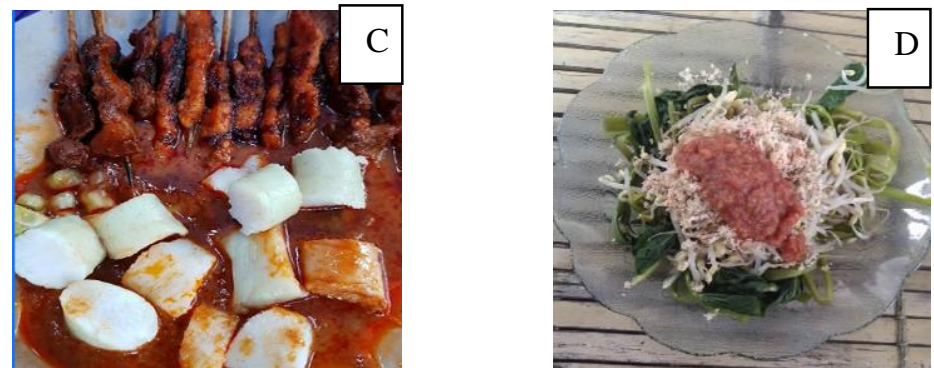

Fig. 1. Material of PjBL: sate pusut (A), poteng reket (B), sate bulayak (C), and pelecing kangkung (D).

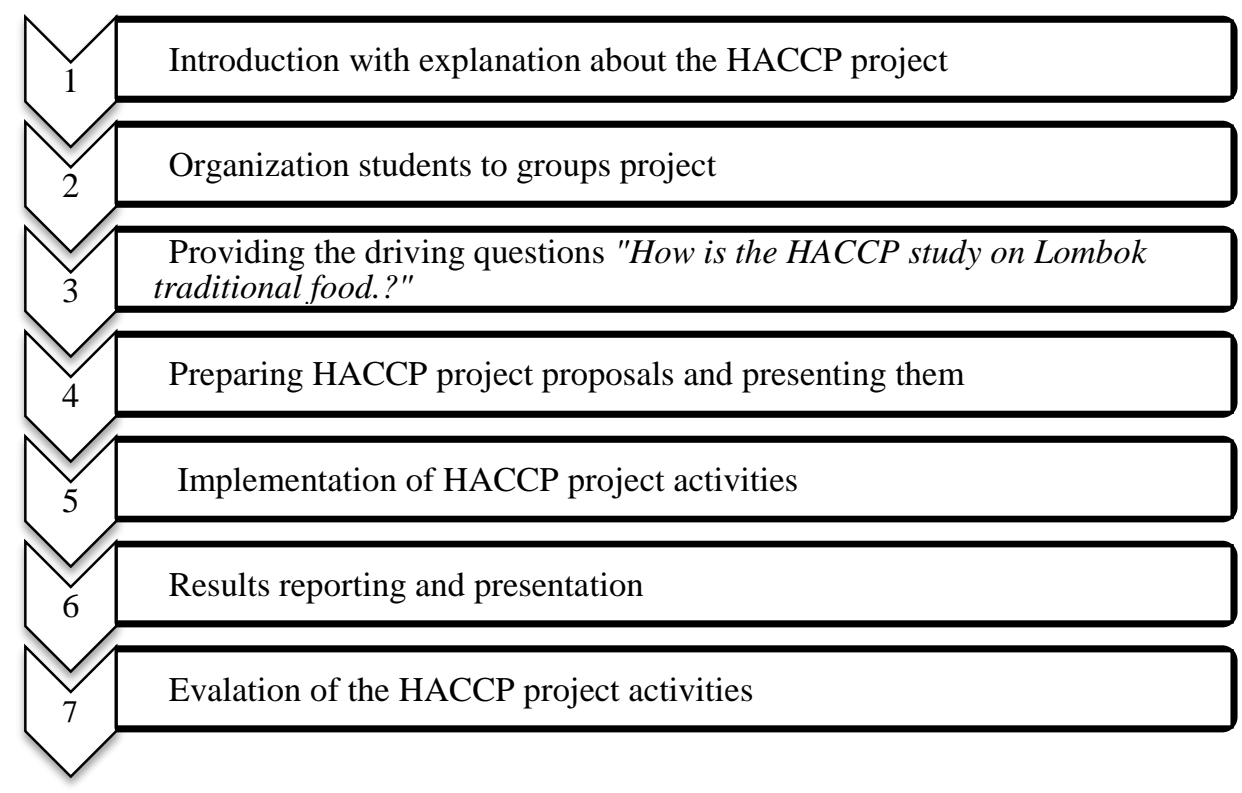

Fig. 2. PjbL steps on the study HACCP traditional food.

\section{Results and Discussion}

All groups were able to conduct Lombok traditional food HACCP studies both in terms of raw materials aspects and processing (table 1). Based on the finding, all groups are very good to describe products and compile processing flow diagrams. Each group has understood the characteristics of traditional food and how they can be processed because it has often been found in various events. This can be understood because some members of each group are accustomed to traditional food processing, especially women. Preparation of product descriptions and processing flow diagrams will help each group analyze the hazards and identify CCPs. 
Table 1. Results of groups' performance on the study of HACCP traditional food.

\begin{tabular}{lcccc}
\hline HACCP component & Group A & Group B & Group C & Group D \\
\hline Product description & 10.00 & 0.00 & 10.00 & 0.00 \\
Processing flow diagram & 15.00 & 5.00 & 15.00 & 5.00 \\
Hazard analysis & 22.50 & 2.50 & 22.50 & 2.50 \\
Determine the CCPs & 22.50 & 5.00 & 22.50 & 5.00 \\
Preventive action & 11.25 & 1.25 & 11.25 & 1.25 \\
Score total & 81.25 & 3.75 & 81.25 & 3.75 \\
Percentage & $81.25 \%$ & $3.75 \%$ & $81.25 \%$ & $.75 \%$ \\
\hline
\end{tabular}

The student's ability to analyze the hazard is quite well. The knowledge about the characteristics of raw materials and various types of hazards is a major factor in being able to conduct a proper hazard analysis. There is a positive correlation between food safety knowledge and the ability to apply it [18]. Failure to identify the correct hazard and to evaluate hazard analysis can render the entire HACCP plan ineffective [19]. Through PjBL each group has an active discussion in conducting a hazard analysis to decide if there is a potential hazard to each raw material. They are critical to achieving good results in the analysis of hazards. For example, group D conducted a hazard analysis on water spinach (Ipomoea aquatica) as the main raw material for pelecing kangkung. They note that the main potential hazard that can occur is contaminated by heavy metals such as cadmium and lead. This is according to their analysis of several locations of water spinach planting which are on the river flow which is weakened by garbage and waste. What was reported by group $\mathrm{D}$ is parallel with many studies that reveal that water spinach plants can absorb heavy metals which are widely used as phytoremediation materials [20]. Through PjBL, the students constructed their own knowledge through active learning and interaction with their teammates, the food producer, and other students in the course [21].

In addition to hazard analysis, the determination of CCPs is the most important step in the design of a HACCP system. Complete and accurate determination of CCPs is fundamental to controlling food safety hazards [22]. CCPs can be determined using decision tree diagrams. Again, knowledgeable and experienced students have essential resources for the group at this time. While not as good as the hazard analysis step, each group can already comprehend the essence of CCPs. Each group includes almost all stages as CCPs, although it is not possible to classify several stages as CCPs. The positive thing that can be taken is that each stage has been shown to have a level of awareness that has to be optimally controlled. This is a good beginning as a learning process because it is their first experience. By frequently carrying out HACCP studies on daily food, they can improve their skills [23]. Next, to avoid repeated errors, preventive action is taken. Preventive action which conducts by each group is well. Common principles among group members are needed to prevent miscommunication if a hazard later occurs. Good communication will encourage adequate precautions. PjBL taught students' skills associated with communication and project management that students would not acquire in normally courses [24].

The student's response to the PjBL was so well. The following of several students response:

"The project is interesting, adding insight into food science as it relates to everyday life."

"The food safety project is beneficial for the community. This is a means to be more careful in processing food or tools used when processing food." 
"The learning is interesting, it is not boring because it finds a new learning condition. Moreover, the project makes us more motivated to learn. We feel for ourselves because we are able to make valuable projects ourselves."

Based on the responses of the students, they feel motivated and interested in doing PjBL. Motivation has a reciprocal relation to learning and performance. Motivation influences learning and performance and what students do and learn influences their motivation [24]. In social cognitive theory, students' learning is viewed as most effective when it is self-regulated, which occurs when students understand, monitor, and control their motivation and behavior. Motivated students achieve academically by engaging in behavior such as question-asking, advice seeking, studying, and participating in classes, labs, and study groups [25]. Work in a team like PjBL gives many advantages for students such as motivation, social cohesion, cognitive advantages, cognitive elaboration, and interpersonal skills and self-awareness [15]. Teams can work well when each team member has a specific role. In this project, some behave as team leaders, the section on hazard analysis, identifying critical points and determining preventive measures. This divided duty gives them a sense of personal responsibility for each member.

Motivation can also be seen in physical activity for example by their efforts in learning. Effort students in this PjBL are shown by their ability in designing projects. The completion of project activities in a timely manner as agreed at the beginning of learning has proven the motivation of students. The autonomy given in designing their project makes the motivation and confidence of students increases. The PjBL has also provided an opportunity for students to receive more practice in giving an oral presentation. By preparing a draft proposal, presentation slides, and final report, students learn and review their basic writing skills [26]. The PjBL then becomes interesting with its real-world characteristics. The actualization of students' interest in learning depends on the characteristics of the learning context. Contexts related to daily life such as food are very effective in making learning more interesting [27]. This PjBL activity is carried out by utilizing traditional food that is so easily obtained and affordable.

Another finding from this $\mathrm{PjBL}$ is that so far students only know that food safety guarantees are carried out by assessing food products after it is made. They don't know anything about the concept of HACCP. Through this project, they understood that food safety assurance by the food industry uses the HACCP concept. They also become more aware to pay attention to food safety. This awareness is needed to avoid the occurrence of foodborne diseases that often occur in many developing countries like Indonesia.

\section{Conclusion}

This PjBL has given the students experience to design their own learning activities in a study of the HACCP traditional food of Lombok. Students did well the study HACCP traditional food through PjBL. In addition, students gave were positive motivation and feel enthusiastic about this PjBL. It encourages students to become more aware of the safety of food which they processing and eat.

Acknowledgments. The authors acknowledge the following: BPPDN Scholarship (Indonesia Postgraduate Education Scholarship) by Directorate General of Higher Education of Indonesia (Grant No. 1014/UN10.14/KU/2013). 


\section{References}

[1] Grace D. (2015). Food safety in low and middle-income countries. International Journal of Environmental Research and Public Health, 12: 10490-10507. doi: 10.3390/ijerph120910490.

[2] BPOM RI. 2017. Laporan tahunan BPOM. Jakarta: Badan Pengawas Obat dan Makanan Republik Indonesia.

[3] Wallace, C. A., Sperber, W. H., \& Mortimore, S. E. (2018). Food safety for the $21^{\text {st }}$ century: Managing HACCP and food safety throughout the global supply chain $2^{\text {nd }}$ edition. Great Britain: John Wiley \& Sons Ltd.

[4] Carrascosa C, Millan R, Saavedra P, Jaber JR, Raposo A, and Sanjuán E. (2016). Identification of the risk factors associated with cheese production to implement hazard analysis and critical control points (HACCP) system on cheese farms. Journal of Dairy Science, 99(4): 2606-2616. doi: $10.3168 /$ jds.2015-10301.

[5] Al-Busaidi MA, Jukes DJ, and Bose S. (2017). Hazard analysis and critical control point (HACCP) in seafood processing: an analysis of its application and use in regulation in the Sultanate of Oman. Food Control, 73: 900-915. doi: 10.1016/j.foodcont.2016.09.042.

[6] Dalgıç AC and Belibağlı KB. (2008). Hazard analysis critical control points implementation in traditional foods: a case study of Tarhana processing. International Journal of Food Science and Technology, 43: 1352-1360. doi: 10.1111/j.1365-2621.2007.01619.x.

[7] Kurnia N, Liliasari, Adawiyah DR, and Supriyanti FMT. (2016). Aspek fungsional dan keamanan pangan Lombok untuk perkuliahan kimia bahan makanan. Prosiding Seminar Nasional Kimia, 6-7 Agustus 2016. Mataram: Jurusan Kimia FMIPA Universitas Mataram.

[8] Benkerroum N. (2013). Traditional fermented foods of North African Countries: Technology and food safety challanges with regard to microbiological risks. Comprehensive Reviews in Food Science and Food Safety, 12(1): 54-89. doi: 10.1111/j.1541-4337.2012.00215.x.

[9] Lee YC, Kung HF, Wu CH, Hsu HM, Chen HC, Huang TC, and Tsai YH. (2016). Determination of histamine in milkfish stick implicated in food-borne poisoning. Journal of Food and Drug Analysis, 24(1): 63-71. doi: 10.1016/j.jfda.2015.06.009

[10] Huang M and Penning TM. (2014). Processing contaminants: polycyclic aromatic hydrocarbons (PAHs). Encyclopedia of Food Safety, 416-423. doi:10.1016/b978-0-12-378612-8.00212-2.

[11] Kurnia N and Marwatoen F. (2012). Penentuan kadar sianida daun singkong dengan variasi umur daun dan waktu pemetikan. Hydrogen: Jurnal Kependidikan Kimia, 1(2): 117-121. doi: 10.33394/hjkk.v1i2.636.

[12] Saraswati MMD and Hardinsyah. (2012). Pengetahuan dan perilaku konsumsi mahasiswa putra tingkat persiapan bersama IPB tentang monosodium glutamat dan keamanannya. Jurnal Gizi dan Pangan, 7(2): 111-118. doi: 10.25182/jgp.2012.7.2.111-118

[13] Al-Shabib NA, Husain FM, and Khan JM. (2017). Study on food safety concerns, knowledge, and practices among university students in Saudi Arabia. Food Control, 73: 202-208. doi: 10.1016/j.foodcont.2016.08.005.

[14] Beier ME, Kim MH, Saterbak A, Leautaud V, Bishnoi S, and Gilberto JM. (2018). The effect of authentic project-based learning on attitudes and career aspirations in STEM. Journal of Research in Science Teaching, 1-21. doi: 10.1002/tea.21465

[15] Markham, T. (2012). Project-based learning design and coaching guide. Canada: Wilsted \& Taylor Publishing Services. p.59.

[16] Hakim A, Liliasari, Kadarohman A, and Syah YM. (2016). Making a natural product chemistry course meaningful with a mini project laboratory. Journal of Chemical Education, 93(1): 193-196. doi: 10.1021/ed500930s

[17] Fraenkel JR, Wallen NE, and Hyun HH. (2012). How to design and evaluate research in education. San Francisco: Mc Graw Hill. p.15.

[18] Ko WH. (2013). The relationship among food safety knowledge, attitudes and self-reported HACCP practices in restaurant employees. Food Control, 29: 192-197. doi: 10.1016/j.foodcont.2012.05.076. 
[19] Ryu K, Park KH, Yang JY, and Bahk GJ. (2013). Simple approach in HACCP evaluating the risk level of hazard using probability distributions. Food Control, 30: 459-462. doi: 10.1016/j.foodcont.2012.07.042

[20] Chanu, LB and Gupta, A. (2016). Phytoremediation of lead using Ipomoea aquatica Forsk. in hydroponic solution. Chemosphere, 156: 407-411. doi: 10.1016/j.chemosphere.2016.05.001.

[21] Frank M, Lavy I, and Elata D. (2003). Implementing the project-based learning approach in an academic engineering course. International Journal of Technology and Design Education, 13(3): 273288. doi: 10.1023/A:1026192113732.

[22] Doménech, E., Escriche, I., \& Martorell, S. (2008). Assessing the effectiveness of critical control points to guarantee food safety. Food Control, 19(6), 557-565. doi:10.1016/j.foodcont.2007.06.015.

[23] Mortimore S. (2001). How to make HACCP really work in practice?. Food Control, 12: 209-215. doi: 10.1016/S0956-7135(01)00017-2

[24] Musa F, Mufti N, Latiff RA, and Amin MM. (2011). Project-based learning: promoting language learning for workplace skills. Procedia Social and Behavioral Sciences, 18: 187-195. doi: 10.1016/j.sbspro.2011.05.027

[25] Pintrich, P. R. (2003). A Motivational Science Perspective on the Role of Student Motivation in Learning and Teaching Contexts. Journal of Educational Psychology, 95(4), 667686. doi:10.1037/0022-0663.95.4.667.

[26] Ablin L. (2018). Engaging students with the real world in a green organic chemistry laboratory group project: A presentation and writing assignment in a laboratory class. Journal of Chemical Education, 95(5): 817-822. doi: 10.1021/acs.jchemed.7b00570.

[27] Bayline JL, Tucci HM, Miller DW, Roderick KD, and Brletic PA. (2018). Chemistry of candy: A sweet approach to teaching nonscience majors. Journal of Chemical Education, 95(8): 1307-1315. doi: 10.1021/acs.jchemed.7b00739 